\title{
Thermal Shock Tolerances of Six Fishes and One Invertebrate from the Pacific Northwest
}

by

J. W. Young

C. W. Apts

September 1977

Prepared for the Energy Research and Development Administration under Contract EY-76-C-06-1830 


\section{NOTICE}

This report was prepared as an account of work sponsored by the United States Government. Neither the United States nor the Energy Research and Development Administration, nor any of their employees, nor any of their contractors, subcontractors, or their employees, makes any warranty, express or implied, or assumes any legal liability or responsibility for the accuracy, completeness or usefulness of any intormation, apparatus, product or process disclosed, or represents that its use would not infringe privately owned rights.

The views, opinions and conclusions contained in this report are those of the contractor and do not necessarily represent those of the United States Government or the United States Energy Research and Development Administration.

PACIFIC NORTHWEST LABORATORY

operated by

BATTELLE

for the

ENERGY RESEARCH AND DEVELOPMENT ADMINISTRATION

Under Contract EY-76-C-06-1830

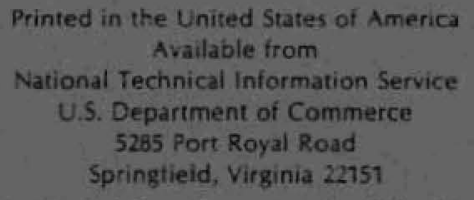

Price: Printed Copy $\$$ *: Microfiche $\$ 3.00$

$\begin{array}{cc}\text { •Pages } & \text { NTIS } \\ 001-025 & \$ 450 \\ 026-050 & \$ 5.00 \\ 051-075 & \$ 5.50 \\ 076-100 & \$ 6.00 \\ 101-125 & \$ 6.50 \\ 126-150 & \$ 7.00 \\ 151-175 & \$ 7.75 \\ 176-200 & \$ 8.50 \\ 201-225 & \$ 5.75 \\ 226-250 & \$ 9.00 \\ 251-275 & \$ 10.00 \\ 276-300 & \$ 10.25\end{array}$


BNWL-2289

Thermal Shock Tolerances

of Six Fishes and One Invertebrate

From the Pacific Northwest

by

James S. Young and Charles W. Apts

BATTELLE

Pacific Northwest Division

Marine Research Laboratory

Route 5, Box 1000

Sequim, Washington 98382 
THERMAL SHOCK TOLERANCES

OF SIX FISHES AND ONE INVERTEBRATE

FROM THE PACIFIC NORTHWEST

The purpose of this study was to ascertain the temperatures at which selected estuarine fishes from the Pacific Northwest and one of their potential food organisms would be incapacitated and killed after entering the thermal plume of an industrial cooling system. This information aids in impact evaluation of thermal discharges, especially where they act as barriers or entrapments.

Some fish are known not to avoid heated effluents during migration (Young and Gibson, 1973), and others may be affected when a sweeping plume impinges on their habitat or territory. The rate of change and magnitude of the temperature may be high enough to overcome thermal resistance and produce shock. Thermally shocked fish become vulnerable prey for other fish and birds (Coutant, 1973; Young and Gibson, 1973).

Adams (1969, cited from DesVoigne, 1970) feels that experiments exposing organisms to rapid temperature elevation better resemble conditions at operating thermal plants than do 24 to 96 -hour tolerance tests. Our report presents equilibrium loss and thermal death as endpoints for different rates of temperature increase of six fishes and one invertebrate. Materials and Methods

The species tested were shiner perch, Cymatogaster aggregata; coho salmon, Onchorhynchus kisutch; Pacific sandlance, Ammodytes hexapterus; threespine stickleback, Gasterosteous aculeatus; silverspotted scuipin, 
| 
Blepsias cirrhosus; Pacific staghorn sculpin, Leptocottus armatus; and the mysid, Mysis oculata. All species were collected from Sequim Bay, Washington, except coho salmon, which were obtained from a local hatchery. They were held for at least two weeks in flow-through aquaria at ambient water temperature $\left(10-17^{\circ} \mathrm{C}, 30 \%\right.$ salinity) before testing. A second group of sticklebacks was held at $20^{\circ} \mathrm{C}$ for two weeks. The Critical Thermal Maximum method was used for determinations. Endpoints were obtained by placing an individual organism in a $2,000 \mathrm{ml}$ volumetric flask containing $1,000 \mathrm{ml}$ of sea water from its holding tank (sandlance and mysids were tested in $500 \mathrm{ml}$ of water). The flask was then placed in a heating mantle that was controlled by a voltage regulator. The voltage regulator, turned to a predetermined setting, provided a given rate of temperature increase. Temperature increase was monitored at one minute intervals with a stem thermometer. Constant aeration was provided to maintain thorough mixing and even temperature distribution in the flask. Equilibrium loss (EL) and death (D) were recorded as the temperature at which the organism became disoriented and the temperature at which opercular movement ceased, respectively. The length and weight of each organism was measured at the conclusion of testing.

The null hypothesis that no differences exist between mean temperatures for equilibrium loss or death for different rates of temperature increase, allowing for possible effects of length and weight, was tested by analysis of covariance. 
. 
Results and Discussion

The rates of temperature increase with corresponding mean weight, mean length, and adjusted EL are given in Table 1. F values are included from analys is of covariance between treatments. Table 2 lists similar data for adjusted D's. Stickleback acclimated at $20^{\circ} \mathrm{C}$, shiner perch, coho salmon, and Pacific sandlance, showed a treatment effect with $95 \%$ confidence for EL. Sticklebacks at both acclimations, shiner perch, and coho salmon, showed a treatment effect with $95 \%$ confidence for D. No significant differences were found in others. The adjusted ELs were consistently a few degrees lower than the corresponding Ds. No EL was exhibited in mysids.

The boundary of a thermal plume may constitute a sharp temperature differential, especially near the plant outlet or where the plume forms a surface layer over cooler water. Fish passing through such a boundary will experience degrees of temperature increase depending on both their swimming speed and the extent of the differential. If the change is rapid and the $\Delta T$ substantial, they will suffer thermal shock. This generally results, first, in a loss of equilibrium often called heat coma and, eventually, in thermal death if the exposure is prolonged, or if the temperature continues to increase.

We continued the temperature increases through equilibrium loss to the point of thermal death because a fish's momentum may carry it through a gradient to the thermal death point after the EL is reached. Many of the menhaden observed by Young and Gibson (1973) swimming into an effluent were thus affected. Some fish, especially the heavier species that have a smaller surface to volume ratio, showed a treatment effect where faster rates of temperature increase resulted in accordingly higher $E L$ and $D$ values. This 
phenomenon results from a time lag between attaining a given environmental temperature and a corresponding deep body temperature. Most individuals exhibited the behavioral response, heat coma, at temperatures one to four degrees below their thermal death point. Some showed no symptoms of heat stress until they reached $D$; thus, the smaller number of tests for some $E L$ determinations. Mysids underwent no obvious heat coma.

We could find little information on upper lethal temperatures for most of the species tested, particularly any involving shock. Jordon and Garside (1972) presented LD50's (time to DS50 was not given) of $25.74^{\circ} \mathrm{C}$ and $27.60^{\circ} \mathrm{C}$ for G. aculeatus acclimated at $10^{\circ} \mathrm{C}$ and $20^{\circ} \mathrm{C}$, respectively, in $30^{\circ} \%$ sea water. Our tests show similarly that heat shock is dependent on acclimation temperature.

Brett (1952) tested the resistance times of young coho salmon acclimated at various temperatures in fresh water. Extrapolation of his data shows a resistance time of about 10 minutes at $27.5^{\circ} \mathrm{C}$. Coutant (1970), though he did not specify the acclimation temperature, found juvenile coho from the Columbia River to resist $29.3^{\circ} \mathrm{C}$ for 10 minutes and $30^{\circ} \mathrm{C}$ for less than 3 minutes, 3 times less tolerant than adults at the latter temperature. Comparison of these observations with ours is difficult because of differences in test conditions, size of fish, and salinity of the water.

Mysids, though a minor food of juvenile coho salmon (Manzer, 1969), are important in the diet of other estuarine fishes (Hair, 1971). Hair, while investigating thermal shock in Neomys is awatschens is, found $87^{\circ} \mathrm{F}\left(30.6^{\circ} \mathrm{C}\right)$ to be a death point regardless of acclimation temperature. This value corresponds well with ours for Mysis oculata. 
$\bullet$

: 
For each species, we attempted to use animals of similar size. However, since differences in size may affect resistance times, the mean ELs and Ds were adjusted for length and weight. These values may stand only for the sizes of organisms tested.

\section{Conclusions}

As our population grows, the Pacific Northwest will depend on increasing use of industries using sea water cooling systems. The information contained here will add to the knowledge of the biological impacts of their impingement on the relatively unpolluted coastal zone, an area that contributes to a large part of the local economy. 
Table 1. Treatments with corresponding number of tests, mean weight and length, and adjusted EL for each species tested. Asterisked F-values for analyses of covariance indicate with $95 \%$ confidence that the null hypothesis is rejected. Degrees of freedom are $\mathrm{K}-1$ and $\mathrm{N}-\mathrm{K}-2$ where $\mathrm{K}=$ number of treatments, $\mathrm{N}=$ total number of tests, and $2=$ number of covariates.

\begin{tabular}{|c|c|c|c|c|c|c|}
\hline Species & $\begin{array}{c}\text { Treatment } \\
\left({ }^{\circ} \mathrm{C} \text { increase/min. }\right)\end{array}$ & $\begin{array}{l}\text { Number } \\
\text { of tests }\end{array}$ & $\begin{array}{l}\text { Mean } \\
\text { Weight (g) }\end{array}$ & $\begin{array}{c}\text { Mean } \\
\text { Length }(\mathrm{mm}) \text {. }\end{array}$ & $\begin{array}{l}\text { Adjusted } \\
\text { EL }\left({ }^{\circ} \mathrm{C}\right)\end{array}$ & F-value \\
\hline \multirow[t]{2}{*}{ Cymatogaster aggregata } & $\begin{array}{l}0.5 \\
1.0\end{array}$ & $\begin{array}{l}10 \\
10\end{array}$ & $\begin{array}{l}3.93 \\
4.56\end{array}$ & $\begin{array}{l}66 \\
70\end{array}$ & $\begin{array}{l}27.3 \\
28.3\end{array}$ & $6.075 *$ \\
\hline & $\begin{array}{l}2.0 \\
6.0\end{array}$ & $\begin{array}{r}5 \\
10\end{array}$ & $\begin{array}{l}6.60 \\
6.89\end{array}$ & $\begin{array}{l}76 \\
74\end{array}$ & $\begin{array}{l}29.2 \\
31.2\end{array}$ & $10.457^{*}$ \\
\hline $\begin{array}{l}\text { Oncorhynchus kisutch } \\
\text { (juveniles) }\end{array}$ & $\begin{array}{l}2.0 \\
6.0\end{array}$ & $\begin{array}{r}5 \\
10\end{array}$ & $\begin{array}{l}13.9 \\
13.0\end{array}$ & $\begin{array}{l}112 \\
105\end{array}$ & $\begin{array}{l}29.2 \\
31.0\end{array}$ & $24.168^{*}$ \\
\hline Ammodytes hexapterus & $\begin{array}{r}2.0 \\
10.0\end{array}$ & $\begin{array}{r}5 \\
10\end{array}$ & $\begin{array}{l}0.68 \\
0.73\end{array}$ & $\begin{array}{l}65 \\
65\end{array}$ & $\begin{array}{l}25.5 \\
26.6\end{array}$ & $5.828^{\star}$ \\
\hline Blepsias cirrhosus & $\begin{array}{l}2.0 \\
6.0\end{array}$ & $\begin{array}{r}5 \\
10\end{array}$ & $\begin{array}{l}0.99 \\
1.06\end{array}$ & $\begin{array}{l}53 \\
52\end{array}$ & $\begin{array}{l}25.0 \\
25.8\end{array}$ & 0.888 \\
\hline Leptocottus armatus & $\begin{array}{l}2.0 \\
6.0\end{array}$ & $\begin{array}{l}4 \\
9\end{array}$ & $\begin{array}{l}2.61 \\
1.85\end{array}$ & $\begin{array}{l}64 \\
57\end{array}$ & $\begin{array}{l}28.4 \\
31.1\end{array}$ & 2.599 \\
\hline$\frac{\text { Gasterosteus }}{\left(10^{\circ} \mathrm{C} \text { acclimation }\right)}$ & $\begin{array}{l}2.0 \\
6.0\end{array}$ & $\begin{array}{l}4 \\
4\end{array}$ & $\begin{array}{l}3.72 \\
3.08\end{array}$ & $\begin{array}{l}78 \\
71\end{array}$ & $\begin{array}{l}30.4 \\
31.4\end{array}$ & 1.216 \\
\hline$\frac{\text { Gasterosteus aculeatus }}{\left(20^{\circ} \mathrm{C} \text { acclimation }\right)}$ & $\begin{array}{l}2.0 \\
6.0\end{array}$ & $\begin{array}{l}5 \\
7\end{array}$ & $\begin{array}{l}3.07 \\
3.06\end{array}$ & $\begin{array}{l}74 \\
74\end{array}$ & $\begin{array}{l}31.5 \\
34.3\end{array}$ & $15.494 *$ \\
\hline Mysis oculata & $\begin{array}{l}2.0 \\
7.0\end{array}$ & $\begin{array}{r}5 \\
10\end{array}$ & $\begin{array}{l}0.041 \\
0.032\end{array}$ & $\begin{array}{l}15 \\
17\end{array}$ & - & - \\
\hline
\end{tabular}


-

. 
Table 2. Treatments with corresponding number of tests, mean weight and length, and adjusted $D$ for each species tested. Asterisked F-values for analyses of covariance indicate with $95 \%$ confidence that the null hypothesis is rejected. Degrees of freedom are $\mathrm{K}-1$ and $\mathrm{N}-\mathrm{K}-2$ where $\mathrm{K}=$ number of treatments, $\mathrm{N}=$ total number of tests, and $2=$ number of covariates.

\begin{tabular}{|c|c|c|c|c|c|c|}
\hline Species & $\left(\begin{array}{l}\text { Treatment } \\
\left({ }^{\circ} \mathrm{C} \text { increase/min. }\right)\end{array}\right.$ & $\begin{array}{l}\text { Number } \\
\text { of tests }\end{array}$ & $\begin{array}{l}\text { Mean } \\
\text { Weight (g) }\end{array}$ & $\begin{array}{l}\text { Mean } \\
\text { Length (mm) }\end{array}$ & $\begin{array}{l}\text { Adjusted } \\
\mathrm{D}\left({ }^{\circ} \mathrm{C}\right)\end{array}$ & F-value \\
\hline \multirow[t]{2}{*}{ Cymatogaster aggregata } & $\begin{array}{l}0.5 \\
1.0\end{array}$ & $\begin{array}{l}10 \\
10\end{array}$ & $\begin{array}{l}3.93 \\
4.56\end{array}$ & $\begin{array}{l}66 \\
70\end{array}$ & $\begin{array}{l}29.4 \\
31.1\end{array}$ & $115.882^{\star}$ \\
\hline & $\begin{array}{l}2.0 \\
6.0\end{array}$ & $\begin{array}{r}5 \\
10\end{array}$ & $\begin{array}{l}6.60 \\
6.89\end{array}$ & $\begin{array}{l}76 \\
74\end{array}$ & $\begin{array}{l}30.7 \\
33.6\end{array}$ & $94.844^{\star}$ \\
\hline$\frac{\text { Oncorhynchus kisutch }}{\text { (juveniles) }}$ & $\begin{array}{l}2.0 \\
6.0\end{array}$ & $\begin{array}{r}5 \\
10\end{array}$ & $\begin{array}{l}13.9 \\
13.0\end{array}$ & $\begin{array}{l}112 \\
105\end{array}$ & $\begin{array}{l}30.1 \\
31.8\end{array}$ & $151.120 *$ \\
\hline Ammodytes hexapterus & $\begin{array}{r}2.0 \\
10.0\end{array}$ & $\begin{array}{r}5 \\
10\end{array}$ & $\begin{array}{l}0.68 \\
0.73\end{array}$ & $\begin{array}{l}65 \\
65\end{array}$ & $\begin{array}{l}27.8 \\
28.9\end{array}$ & 3.797 \\
\hline Blepsias cirrhosus & $\begin{array}{l}2.0 \\
6.0\end{array}$ & $\begin{array}{r}5 \\
10\end{array}$ & $\begin{array}{l}0.99 \\
1.06\end{array}$ & $\begin{array}{l}53 \\
52\end{array}$ & $\begin{array}{l}27.7 \\
27.9\end{array}$ & 0.160 \\
\hline Leptocottus armatus & $\begin{array}{l}2.0 \\
6.0\end{array}$ & $\begin{array}{r}5 \\
10\end{array}$ & $\begin{array}{l}2.42 \\
1.87\end{array}$ & $\begin{array}{l}62 \\
57\end{array}$ & $\begin{array}{l}32.5 \\
32.2\end{array}$ & 0.224 \\
\hline$\frac{\text { Gas terosteus acul eatus }}{\left(10^{\circ} \mathrm{C} \text { acclimation }\right)}$ & $\begin{array}{l}2.0 \\
6.0\end{array}$ & $\begin{array}{r}5 \\
10\end{array}$ & $\begin{array}{l}3.92 \\
3.79\end{array}$ & $\begin{array}{l}79 \\
73\end{array}$ & $\begin{array}{l}32.0 \\
33.0\end{array}$ & $11.867^{\star}$ \\
\hline$\frac{\text { Gasterosteus }}{\left(20^{\circ} \mathrm{C} \text { acclimation }\right)}$ & $\begin{array}{l}2.0 \\
6.0\end{array}$ & $\begin{array}{l}5 \\
9\end{array}$ & $\begin{array}{l}3.07 \\
3.18\end{array}$ & $\begin{array}{l}74 \\
75\end{array}$ & $\begin{array}{l}34.9 \\
35.8\end{array}$ & $17.451 \star$ \\
\hline Mysis oculata & $\begin{array}{l}2.0 \\
7.0\end{array}$ & $\begin{array}{r}5 \\
10\end{array}$ & $\begin{array}{l}0.041 \\
0.032\end{array}$ & $\begin{array}{l}15 \\
17\end{array}$ & $\begin{array}{l}30.1 \\
29.9\end{array}$ & 0.139 \\
\hline
\end{tabular}




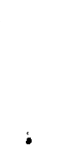

$-$ 


\section{Literature Cited}

Adams, J. R. 1969. Thermal power, aquatic 7 ife, and kilowatts on the Pacific coast. Presented at American Power Conf. Ann. Meeting, Chicago, I11. 22-25. Apri1 1967.

Brett, J. R. 1952. Temperature tolerance in young Pacific salmon, Genus Oncorhynchus. 3. Fish. Res. Bd. Canada 9:265-323.

Coutant, C. C. 1970. Thermal resistance of adult coho (Oncorhynchus kisutch) and jack chinook (0. tshawytscha) salmon, and adult steelhead trout (Salmo gairdneri) from the Columbia River. BNWL-1508, Battelle-Northwest, Richland, Washington.

Coutant, C. C. 1973. Effect of thermal shock on vulnerability of juvenile salmonids to predation. J. Fish. Res. Bd. Canada 30:965-973.

DesVoigne, D. M. 1970. Preliminary observations of the thermal tolerances of selected invertebrate fauna of Sequim Bay, Washington. Northwest Sci. 44:114-122.

Hair, J. R. 1971. Upper lethal temperature and thermal shock tolerances of the opossum shrimp, Neomysis awatschensis, from the Sacramento-San Joaquin estuary, California. Calif. Fish and Game 57:17-27.

Jordan, C. M. and Garside, E. T. 1972. Upper lethal temperatures of threespine stickleback, Gasterosteus aculeatus (L.), in relation to thermal and osmotic acclimation, ambient salinity, and size. Canadian J. Z0ol. 50: 1405-1411.

Manzer, J. I. 1969. Stomach contents of juvenile Pacific salmon in Chatham Sound and adjacent waters. J. Fish. Res. Bd. Canada 26:2219-2223.

Young, J. S. and Gibson, C. I. 1973. Effect of thermal effluent on migrating menhaden. Mar. Poll. Bul1. 4:94-96 
$\checkmark$ 
BNWL -2289

UC -11

\section{DISTRIBUTION}

No. of

Copies

OFFSITE

1 A. A. Churm Chicago Patent Office ERDA 8900 South Cass Ave. Argonne, IL 60439

27 ERDA Technical Information Center

ONSITE

1 ERDA Richland Operations Office

H. E. Ransom
No. of

Copies

ONSITE.

31 Battelle-Northwest

T. Ambrose

C. W. Apts

R. F. Foster

C. I. Gibson

D. E. Olesen

N. M. Sherer

W. L. Templeton

B. E. Vaughan

J. S. Young (15)

Technical Information Files (5)

Technical Publications (3) 
.

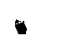

